\title{
34. EXTENTS AND IMPLICATIONS OF ORGANIC MATTER ALTERATION AT OXIDATION FRONTS IN TURBIDITES FROM THE MADEIRA ABYSSAL PLAIN ${ }^{1}$
}

\author{
Gregory Cowie, ${ }^{2}$ Stephen Calvert, ${ }^{3}$ Gert De Lange, ${ }^{4}$ Richard Keil, ${ }^{5}$ and John Hedges ${ }^{5}$
}

\begin{abstract}
Organic geochemical, stable $\mathrm{N}$ isotope, and mineral surface area analyses were made on samples spanning oxidation fronts at the tops of organic matter-rich turbidites from Sites 951 and 952 on the Madeira Abyssal Plain (MAP), off northwest Africa. These oxidation fronts permit the isolation of the effects of oxygen exposure on sedimentary organic matter preservation.

Organic matter contents of the unoxidized turbidites, which originate on the productive northwest African margin, vary, but contents within a given turbidite are uniform. Across the oxidation fronts, most of the organic material previously preserved for extended periods in the absence of oxygen is lost, resulting in contents typical of pelagic sediments. Organic carbon-to-total nitrogen ratios drop, partly or wholly the result of preservation or immobilization of inorganic N. Lignin yields in the unoxidized turbidites are low, consistent with a minor terrestrial organic component, as is also indicated by C:N ratios and previous biomarker studies. Lignin losses across the fronts parallel those of organic $\mathrm{C}$, indicating nonselective degradation of terrestrial relative to marine organic material. Stable $\mathrm{N}$-isotope compositions shift to heavier values across the fronts, from compositions typical of many marine sediments. The shifts resemble early diagenetic patterns in oxygenated marine settings, but the degree to which they result from preservation or immobilization of inorganic $\mathrm{N}$ remains unclear.

Mineral surface areas show a roughly inverse relationship with relative contents of $\mathrm{CaCO}_{3}$, both within the unoxidized turbidites and across the oxidation fronts. In the latter case, surface areas rise with a decrease in $\mathrm{CaCO}_{3}$, presumably because of dissolution of the (coarse) carbonate fraction. Organic carbon contents drop from loadings near the "monolayer equivalent" relative to the available surface area, which is typical of continental margin sediments deposited under suboxic conditions, to "submonolayer" loadings typical of oxygenated pelagic sediments. Thus, in effect, oxidation occurring at the MAP oxidation fronts converts organic matter-rich continental margin sediments into organic matter-lean pelagic deposits. This result clearly indicates that, in the pelagic realm, where exposure is normally long, oxygen availability is a primary control on sedimentary organic matter content.
\end{abstract}

\section{INTRODUCTION}

The Madeira Abyssal Plain (MAP), at an average water depth of $\sim 5400 \mathrm{~m}$ and covering an approximate area of $80,000 \mathrm{~km}^{2}$, forms the bottom of the Canary Basin (Fig. 1). One of the objectives of coring at Sites 950, 951, and 952 during Leg 157 (Fig. 2) was to "analyze the long term effects of sediment burial and diagenesis in a sequence of mixed volcanic, organic-rich, and organic-poor sediments" (Shipboard Scientific Party, 1995).

MAP records are dominated by a sequence of often meter-thick, distal turbidites, each event representing $100 \mathrm{~km}^{3}$ or more of deposition. These are typically intercalated with thin (tens of centimeters) layers of organic matter-poor, pelagic marls that often represent tens of thousands of years of deposition. The turbidites differ in origin and composition. Green, organic matter-rich turbidites derive from the productive northwest African margin, north or the south of the Canaries, whereas gray, volcaniclastic turbidites originate on the slopes of the Canary and Madeira Islands, and white, calcareous turbidites come from seamounts to the west of the MAP (Fig. 1).

An exceptional feature of the MAP sediment records, most noticeable in the organic matter-rich turbidites, is that post-depositional penetration of oxygen by diffusion or bioturbation has created "oxidation fronts" with clear color changes (to paler green) at the tops of

${ }^{1}$ Weaver, P.P.E., Schmincke, H.-U., Firth, J.V., and Duffield, W. (Eds.), 1998. Proc. ODP, Sci. Results, 157: College Station, TX (Ocean Drilling Program).

${ }^{2}$ Marine Geosciences Unit, Geology and Geophysics Department, University of Edinburgh, West Mains Road, EH9 3JW, Scotland. glcowie@glg.ed.ac.uk

${ }^{3}$ Oceanography Department, University of British Columbia, 6270 University Boulevard, Vancouver B.C., V6T 1Z4, Canada.

${ }^{4}$ Department of Geochemistry, Institute of Earth Sciences, Ütrecht University, 3584 CD Ütrecht, The Netherlands.

${ }^{5}$ University of Washington, School of Oceanography, Box 357940, Seattle, WA 98195-7940, U.S.A. many turbidites (e.g., De Lange et al., 1987). Sedimentary organic material previously preserved for extended periods in the absence of oxygen, both at the original continental margin deposition site and on the MAP, is extensively degraded when re-exposed to oxygen (De Lange et al., 1987; Prahl et al., 1989; Cowie et al., 1995). The finegrained turbidites are typically homogeneous (e.g., De Lange et al., 1987) other than occasional, thin silty layers at their bases. The oxidation fronts, therefore, provide a rare instance where the role of oxygen availability in determining sedimentary organic matter pres-

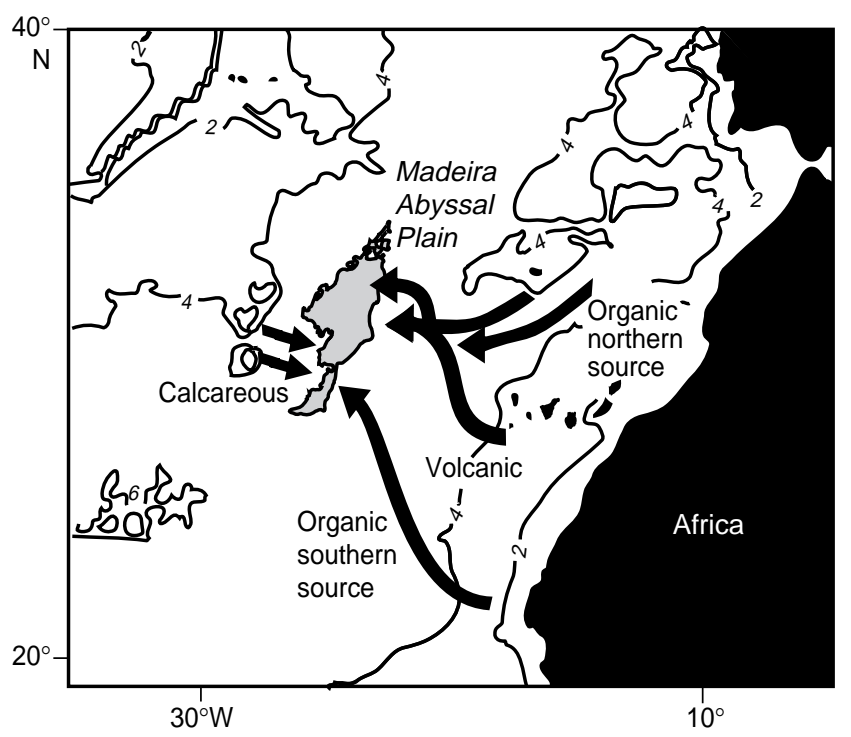

Figure 1. Location of the Madeira Abyssal Plain and sources of various turbidite types. Contours are in kilometers. 


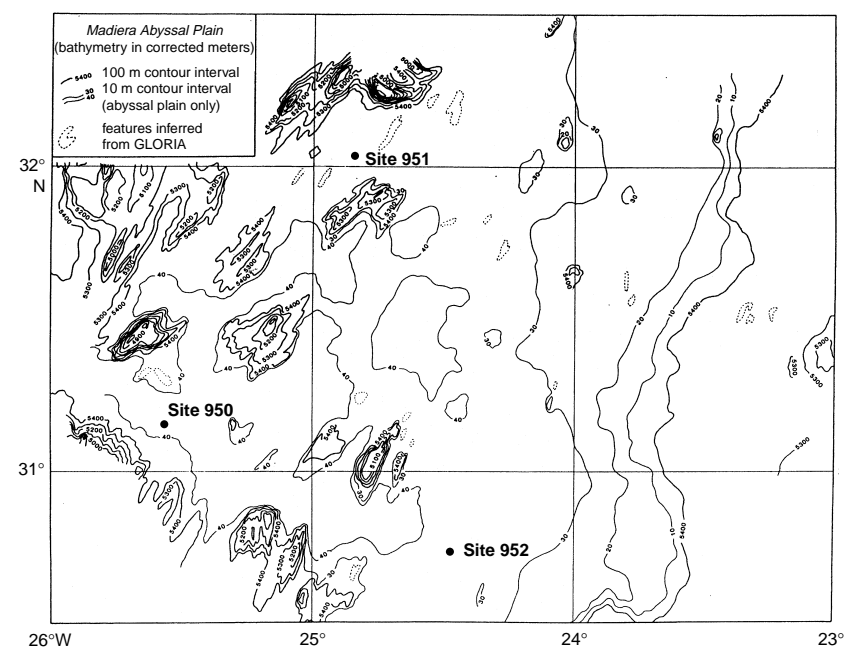

Figure 2. Bathymetric map of the central part of the Madeira Abyssal Plain showing locations of Sites 950, 951, and 952. Contours are in corrected meters.

ervation, a subject of considerable debate (e.g., Demaison and Moore, 1980; Calvert and Pedersen, 1992; Canfield, 1994; Hedges and Keil, 1995; Tyson, 1995), is unambiguously revealed.

Piston cores collected on previous MAP expeditions in the late 1970s and 1980s have been the subject of extensive geochemical investigation. Detailed organic geochemical studies of samples spanning oxidation fronts, however, have been limited to studies of the relict "F-turbidite" (seventh in depth sequence), found at roughly 7$10 \mathrm{~m}$ depth in cores from various MAP locations (e.g., Prahl et al., 1989; Cowie et al., 1995). Briefly, these studies have shown dramatic decreases in bulk $\mathrm{C}$ and $\mathrm{N}$ contents across MAP oxidation fronts, dropping to values closely resembling those in the intercalated pelagic sediments. These results clearly indicate that, in this abyssal setting, oxygen exposure is a primary control on sedimentary organic matter content. The oxidation process is obviously severe, including removal of pollen (Keil et al., 1994a), but, with some exceptions, is generally nonselective at the molecular level compared with diagenetic patterns observed at early stages of organic alteration (Cowie et al., 1995).

Cores from Sites 950, 951, and 952 show that similar turbidite sequences extend to a few hundreds of meters depth and $~ 15$ Ma (Shipboard Scientific Party, 1995). Many units appear in the records from all three sites, indicating basin-wide deposition at the times of these major turbidite events. However, the records are by no means identical; differences in location relative to source areas are reflected as differences in the sequence and thicknesses of the organic matterrich, volcanic, and calcitic turbidites.

Oxidation fronts were observed at the tops of many of the organic matter-rich turbidites. We describe here results of selected organic geochemical, stable isotope, and mineral surface area analyses of 43 oxidation front samples from cores recovered from Sites 951 and 952. The sites are $>100 \mathrm{~km}$ apart and receive differing contributions from the various turbidite source areas. Among the organic matterrich turbidites, initial organic matter sources and contents vary, both because of differing source locations and because of past variation in $\mathrm{CaCO}_{3}$ contents with fluctuation of the Atlantic calcite compensation depth (CCD). The extent of organic matter alteration, as well as the degree to which oxygen is delivered by diffusion or bioturbation, also differ. Study of these turbidite sequences and oxidation fronts, therefore, potentially offers valuable new information. First, the longer term stability of turbidite organic materials in the absence of oxygen can be established. The effects of turbidite source, the extent of alter- ation, and the mechanism of oxygen supply on compositional changes observed at the oxidation fronts may also be elucidated. Finally, the results will potentially validate information gained from previous studies of more recent oxidation fronts.

\section{DESCRIPTION OF STUDY SECTIONS}

Five- to 10 -cm sample intervals were taken from horizons spanning 12 oxidation fronts ( six from each site) from organic matter-rich turbidites recovered from Sites 951 and 952 and were homogenized. Single samples were taken from oxidized horizons, whereas two or three samples were collected from reducing horizons below the oxidation fronts.

In the case of Site 951, samples were taken from both Holes A and B. Oxidation fronts were sampled at $\sim 60.6,95.0,128.2,161.7$, and $221.8 \mathrm{~m}$ below seafloor (mbsf) in Hole $951 \mathrm{~A}$, and $279.6 \mathrm{~m}$ below the surface in Hole 951B. At Site 952, samples were all taken from Hole 952A and oxidation fronts were sampled at $\sim 42.4,83.0,133.5,159.7$, 210.4, and 247.4 mbsf.

\section{METHODS}

All samples were freeze-dried and then gently ground by mortar and pestle to break up aggregates while minimizing particle damage. Inorganic $\mathrm{C}$ (expressed as $\mathrm{CaCO}_{3}$ ) contents were determined with a Coulometrics $\mathrm{CO}_{2}$ coulometer calibrated with reagent-grade calcite, with replicate analyses showing $\leq 1.3 \%(2 \sigma)$ error. Total N, C, and S contents were determined with a Carlo Erba NA1500 NCS analyzer (with $\leq 2.1 \%, 1.2 \%$, and $7.4 \%$ error [ $2 \sigma]$, respectively), using reagentgrade acetanilide and sulfanilimide for multipoint calibration. Organic $\mathrm{C}\left(\mathrm{C}_{\text {org }}\right)$ contents were determined by difference with $\leq 1.4 \%$ error $(2 \sigma)$.

Mineral surface areas were determined by the one-point BET (Brunauer-Emmett-Teller adsorption isotherm) method on a Quantachrome Monosorb Surface Area Analyzer. Before analysis, sediments were desalinized via exhaustive rinsing with distilled water, centrifuged $(15 \mathrm{~min}$ at $30,000 \times \mathrm{g}$ ), and freeze-dried. The sediment surfaces were then cleaned of organic matter via heating in an oxygenated atmosphere to $300^{\circ} \mathrm{C}$ for $12 \mathrm{~h}$, followed by a 4-h cooling period. For mineral surface area measurement, flowing nitrogen gas at a mole fraction of 0.28 (the balance being helium) was adsorbed to mineral surfaces at $-77^{\circ} \mathrm{C}$. After adsorption, nitrogen was liberated from the mineral surface by gradual warming and measured by thermal-conductivity detection. Accuracy for BET analyses of known minerals is generally considered to be $\pm 5 \%$. Error for the analyses reported here was $\leq 1 \%(2 \sigma)$.

Stable $\mathrm{N}$ isotope analyses were performed with a VG PRISM mass spectrometer fitted with an on-line Fisons CHN analyzer as the gas preparation device. Results are reported in the standard $\delta(\%)$ notation (relative to atmospheric $\mathrm{N}_{2}$ ), and the error of the measurements was $\pm 0.05 \%$ o $(2 \sigma)$.

Lignin-derived phenols, which in many cases were present in concentrations at or near detection limits, particularly in the oxidized horizons, were determined with an error of $\leq 25 \%(2 \sigma)$ by gas chromatography-flame ionization detection of trimethylsilyl derivatives following $\mathrm{CuO}$ oxidation of bulk sediment samples under alkaline conditions (Hedges and Ertel, 1982). Phenols were quantified relative to internal standards added immediately following oxidation.

\section{RESULTS AND DISCUSSION}

The results of the elemental, stable isotope, and surface area analyses of the 43 Leg 157 samples are reported in Table 1. Yields of in- 
Table 1. Results of elemental, stable $\mathrm{N}$-isotope, and surface area analyses of turbidite samples, Sites 951 and 952.

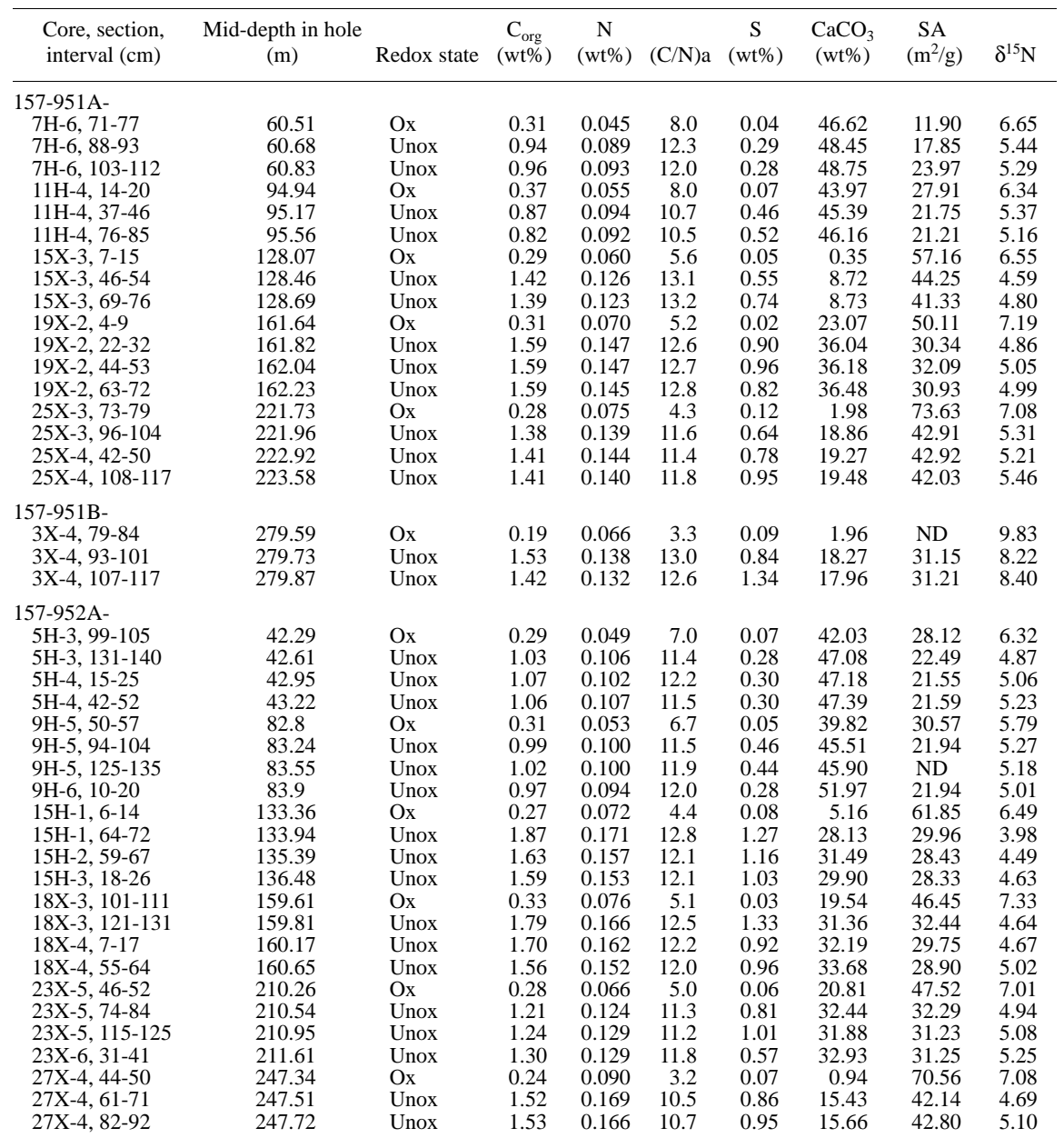

Notes: Redox state = oxidation state of sample (ox = oxidized, unox $=$ unoxidized), $\mathrm{C}_{\text {org }}=$ organic carbon, $\mathrm{N}=$ total $\mathrm{N},(\mathrm{C} / \mathrm{N}) \mathrm{a}=$ atomic ratio of organic $\mathrm{C}$ to total $\mathrm{N}, \mathrm{S}=$ total sulfur, $\mathrm{CaCO}_{3}=$ calcium carbonate, $\mathrm{SA}=$ mineral surface area $\left(\mathrm{m}^{2} / \mathrm{g}\right), \delta^{15} \mathrm{~N}=$ stable $\mathrm{N}$-isotope composition $(\%)$, and $\mathrm{ND}=$ not determined.

dividual and total lignin phenols (normalized to organic carbon, $\mathrm{mg}$ / $100 \mathrm{mg} \mathrm{C}_{\text {org }}$ ) are tabulated separately (Table 2).

\section{Elemental Compositions}

The results of total sulfur analyses of the 12 organic matter-rich turbidites studied here (Table 1), although less precise than those of $\mathrm{C}_{\text {org }}$ and $\mathrm{N}$ analyses, show clear $\mathrm{S}$ losses across the oxidation fronts, presumably the result of oxidation of the pyrite framboids observed in many of the organic matter-rich turbidites (Shipboard Scientific Party, 1995) or of organic sulfur compounds (e.g., de Leeuw et al., 1982). The organic carbon and total nitrogen compositions of the unoxidized turbidites vary considerably from 0.82 to $1.87 \% \mathrm{C}_{\text {org }}$ and 0.089 to $0.17 \% \mathrm{~N}$ (Table 1), without a clear downhole trend. Notably, these differences, combined with those observed in carbonate content (Table 1), are consistent with turbidites from different source regions on the northwest African margin (north or south of the Canaries or farther to the south, off Cap Blanc; see Fig. 1 and Weaver, 1994, although compositions are also influenced (Weaver, 1994). The organic matter compositional differences are caused by varied organic matter supply in the source areas, differing depths of erosion (and thus in the ages of deposits and the extent of organic material alteration), and by entrainment of other surficial sediments during transport to the MAP.
If differences in the preservation state do exist among the turbidites studied here, they do not appear to result from in situ alteration on the MAP. Importantly, the organic matter contents within the unoxidized horizons of all 12 turbidites, including those from the deepest sections of the holes, show no measurable differences (outside analytical precision) over the meter or greater lengths studied (Fig. 3). Thus, the organic materials preserved in these turbidites appear to be stable in the absence of oxygen over million-year time scales. The in situ sulfate reduction and methanogenesis that are apparent from pore-water profiles (Shipboard Scientific Party, 1995) are either insufficient to measurably alter solid-phase organic matter contents or somehow do so uniformly over the length of a given turbidite. The compositional homogeneity of the unoxidized turbidites provides valuable, fixed reference points for quantification of organic matter losses across the oxidation fronts (De Lange et al., 1987; Prahl et al., 1989; Cowie et al., 1995).

The oxidation process occurring at the fronts is clearly severe, removing the majority of $\mathrm{C}_{\text {org }}$ and $\mathrm{N}$ in all cases (Fig. 3). The contents of the oxidized horizons range from 0.19 to $0.37 \% \mathrm{C}_{\text {org }}$ and 0.045 to $0.090 \% \mathrm{~N}$ (Table 1 ), values typical of many organic matter-poor, pelagic sediments. These compare to ranges of $0.82-1.87 \% \mathrm{C}_{\mathrm{org}}$ and $0.089-0.171 \% \mathrm{~N}$ in the unoxidized horizons. Thus, despite considerable differences in initial $\mathrm{C}_{\text {org }}$ content, the oxidized horizons display a narrow range of percent $C_{\text {org }}$ values, and these show no apparent 
Table 2. Organic carbon normalized lignin phenol yields of turbidite samples, Sites 951 and 952.

\begin{tabular}{|c|c|c|c|c|c|c|c|c|c|c|c|c|c|}
\hline $\begin{array}{l}\text { Core, section, } \\
\text { interval }(\mathrm{cm})\end{array}$ & $\begin{array}{l}\text { Mid-depth in hole } \\
\text { (m) }\end{array}$ & Redox state & V-ALD & V-ONE & V-ACID & S-ALD & S-ONE & S-ACID & C-ACID & F-ACID & $\Lambda$ & $\mathrm{S} / \mathrm{V}$ & $\mathrm{C} / \mathrm{V}$ \\
\hline \multicolumn{14}{|l|}{ 157-951A- } \\
\hline $19 \mathrm{X}-2,22-32$ & $\begin{array}{l}161.64 \\
161.82\end{array}$ & $\begin{array}{l}\text { Ux } \\
\text { Unox }\end{array}$ & $\begin{array}{l}0.010 \\
0.020\end{array}$ & $\begin{array}{l}0.003 \\
0.004\end{array}$ & $\begin{array}{l}0.019 \\
0.010\end{array}$ & $\begin{array}{l}0.019 \\
0.021\end{array}$ & $\begin{array}{l}0.012 \\
0.009\end{array}$ & 0.022 & $\begin{array}{l}0.014 \\
0.013\end{array}$ & $\begin{array}{l}0.009 \\
0.010\end{array}$ & $\begin{array}{l}0.106 \\
0.104\end{array}$ & $\begin{array}{l}1.66 \\
1.38\end{array}$ & $\begin{array}{l}0.70 \\
0.68\end{array}$ \\
\hline $19 \mathrm{X}-2,63-72$ & 162.23 & Unox & 0.026 & 0.005 & 0.008 & 0.024 & 0.008 & 0.010 & 0.011 & 0.009 & 0.100 & 1.10 & 0.51 \\
\hline \multicolumn{14}{|l|}{ 157-951B- } \\
\hline $3 \mathrm{X}-4,79-84$ & 279.59 & Ox & 0.030 & 0.004 & 0.011 & 0.016 & 0.008 & 0.026 & 0.008 & 0.009 & 0.112 & 1.10 & 0.38 \\
\hline $3 \mathrm{X}-4,93-101$ & 279.73 & Unox & 0.014 & 0.003 & 0.004 & 0.024 & 0.008 & 0.013 & 0.008 & 0.013 & 0.088 & 2.09 & 1.01 \\
\hline $3 \mathrm{X}-4,107-117$ & 279.87 & Unox & 0.022 & 0.005 & 0.006 & 0.032 & 0.010 & 0.013 & 0.013 & 0.015 & 0.117 & 1.67 & 0.85 \\
\hline \multicolumn{14}{|l|}{$157-952 \mathrm{~A}-$} \\
\hline $18 \mathrm{X}-3,101-111$ & 159.61 & Ox & 0.020 & 0.008 & 0.013 & 0.034 & 0.014 & 0.008 & 0.003 & 0.004 & 0.103 & 1.37 & 0.17 \\
\hline $18 \mathrm{X}-3,121-131$ & 159.81 & Unox & 0.016 & 0.005 & 0.006 & 0.021 & 0.010 & 0.006 & 0.003 & 0.005 & 0.072 & 1.32 & 0.27 \\
\hline $18 X-4,55-64$ & 160.65 & Unox & 0.019 & 0.005 & 0.006 & 0.023 & 0.009 & 0.011 & 0.003 & 0.009 & 0.086 & 1.43 & 0.43 \\
\hline \multicolumn{14}{|l|}{$157-952 \mathrm{~A}-$} \\
\hline $27 \mathrm{X}-4,44-50$ & 247.34 & Ox & 0.025 & 0.011 & 0.006 & 0.024 & 0.012 & 0.008 & 0.018 & 0.004 & 0.108 & 1.00 & 0.51 \\
\hline $27 \mathrm{X}-4,61-71$ & 247.51 & Unox & 0.033 & 0.005 & 0.009 & 0.023 & 0.008 & 0.010 & 0.008 & 0.004 & 0.099 & 0.85 & 0.26 \\
\hline $27 \mathrm{X}-4,82-92$ & 247.72 & Unox & 0.022 & 0.005 & 0.007 & 0.023 & 0.008 & 0.010 & 0.008 & 0.004 & 0.087 & 1.23 & 0.34 \\
\hline
\end{tabular}

Notes: Redox state $=$ oxidation state of sample $(\mathrm{ox}=$ oxidized; unox $=$ unoxidized $)$. V-ALD $=$ vanillin, V-ONE $=$ acetovanillone, $\mathrm{V}-\mathrm{ACID}=$ vanillic acid, $\mathrm{S}-\mathrm{ALD}=$ syringaldehyde, $\mathrm{S}-$ $\mathrm{ONE}=$ acetosyringone, $\mathrm{S}$-ACID $=$ syringic acid, C-ACID $=p$-coumaric acid, F-ACID $=$ ferulic acid, and $\Lambda=$ total lignin phenol yield in $\mathrm{mg} / 100 \mathrm{mg} \mathrm{C}_{\text {org }}\left(\mathrm{C}_{\mathrm{org}}=\right.$ organic carbon [wt\%]). S:V = ratio of sum of syringyl phenols (S-x) to sum of vanillyl phenols (V-x), and C:V = ratio of sum of cinnamyl phenols (C-ACID + F-ACID) to sum of vanillyl (V-x) phenols.

downhole trend (Fig. 3; Table 1). The range of percent $\mathrm{N}$ values in the oxidized horizons is large by comparison and, although we only have results from single intervals for each oxidized turbidite, there appears to be a downhole trend toward higher oxidized percent $\mathrm{N}$ values at both sites. A consistent feature is that oxidation results in a decrease in atomic $\mathrm{C}_{\text {org }}$ to $\mathrm{N}$ ratio, $(\mathrm{C} / \mathrm{N})$ a, from a value range of $10.5-$ 13.2 in the unoxidized turbidites to a range of 3.2-8.0 in the oxidized horizons. The wider range in the oxidized horizons results from the percent $\mathrm{N}$ variability. The lower values in this range are well below values typical of living organisms or "young" organic material ( 510; e.g., Hedges et al., 1988). The trend to lower (C/N)a values is typical of trends observed in previous studies of MAP turbidites (e.g., De Lange, 1992; Cowie et al., 1995). Notably, there appears to be a gradual decrease with depth in the $(\mathrm{C} / \mathrm{N})$ a values of the oxidized horizons (Table 1) because of the gradual increase in percent $\mathrm{N}$ values. No such trend is apparent in the unoxidized turbidites (Table 1).

A plot of percent $\mathrm{C}_{\text {org }}$ against percent $\mathrm{N}$ (Fig. 4) provides a possible explanation for the decrease in $(\mathrm{C} / \mathrm{N})$ a values across the oxidation fronts, which runs counter to the preferential loss of $\mathrm{N}$ observed in many early diagenetic sequences (see Cowie et al., 1995, and references therein). A linear regression of the 31 unoxidized samples yields a best-fit $\left(r^{2}=0.912\right)$ line that passes close to the origin (indicating at most a minor inorganic $\mathrm{N}$ content) and has a slope of 10.6. This suggests that the organic $\mathrm{C}$ and total $\mathrm{N}$ contents of the unoxidized turbidites can be readily explained by differing inputs or preservation of organic material with a $(\mathrm{C} / \mathrm{N})$ a value of 12.4 . This value resembles those observed in the samples themselves and is consistent with a predominance of degraded marine organic material, as indicated by previous biomarker analyses of MAP turbidites (e.g., Cowie et al., 1995; Prahl et al., 1997).

The best-fit linear regression line for all 43 samples $\left(r^{2}=0.914\right)$, including the oxidized horizons, has a markedly higher slope of 13.6, which is equivalent to a $(\mathrm{C} / \mathrm{N})$ a of 15.9 and is higher than that observed in the turbidites. Notably, there is also a considerable percent $\mathrm{N}$ value of $0.035 \%$ at $\% \mathrm{C}_{\text {org }}=0$ (Fig. 4 ), which, in contrast to the regression line for the unoxidixed turbidites, strongly indicates an important inorganic $\mathrm{N}$ content - at least in the oxidized samples. Values for the oxidized samples fall below and to the right of the regression line for the unoxidized samples, values for the deepest samples, with the highest percent $\mathrm{N}$ and lowest $(\mathrm{C} / \mathrm{N})$ a values, being the farthest removed. Collectively, these features indicate that the drop in $(\mathrm{C} / \mathrm{N}) \mathrm{a}$ values across the oxidation fronts may best be explained not by preferential loss of organic $\mathrm{N}$ relative to organic $\mathrm{C}$, but by preservation of inorganic $\mathrm{N}$. This may be the result of preservation of an existing, inert inorganic $\mathrm{N}$ component, as suggested by Cowie et al. (1995), or to the acquisition of inorganic $\mathrm{N}$ during or after the oxidation process. The decrease in $(\mathrm{C} / \mathrm{N})$ a values with depth in the oxidized horizons mirrors the rise in pore-water ammonia concentrations (Shipboard Scientific Party, 1995) and suggests that adsorption of ammonia onto clay minerals (Müller, 1977) may be the overriding process.

\section{Lignin and Stable Isotopes}

Stable isotope and molecular-level organic geochemical analyses provide insights into the source and nature of organic material present in both the unoxidized and oxidized turbidite horizons, as well as into the nature and selectivity of the oxidation process. Total organic carbon-normalized lignin phenol yields $(\Lambda$; Table 2$)$ in the unoxidized horizons of the four turbidites investigated were low $(\leq 0.12 \mathrm{mg} / 100$ $\mathrm{mg}_{\mathrm{org}}$ ) and close to detection limits. Precision was consequently poorer than for the other analytes and resulted in an anomalous apparent inhomogeneity in one of the unoxidized turbidites (Hole 951B, Section 3X). Nonetheless, yields are similar to those previously observed in the more recent F-turbidite (Cowie et al., 1995) and indicate a measurable, but minor, contribution of terrestrial organic material to these deposits. However, phenol compositions are not uniform (Table 2). Although interpretations of phenol compositions are potentially compromised by selective diagenetic alteration, ratios of the sums of syringyl and cinnamyl phenols to the sum of vanillyl phenols ( $\mathrm{S}: \mathrm{V}$ and $\mathrm{C}: \mathrm{V}$, respectively), which provide indications of terrestrial plant type (Hedges and Mann, 1979), suggest that vascular plant communities (or inputs) may have differed in the source area(s) when the sediments from which the various turbidites derive were initially deposited on the northwest African margin.

Lignin appears to have suffered much the same fate as bulk $\mathrm{C}_{\text {org }}$ across the oxidation fronts, resulting in $\Lambda$ values for oxidized horizons that, given analytical uncertainty, are not measurably different from those for unoxidized counterparts (Table 2; Fig. 5). Phenol compositions show few, if any, consistent trends across the oxidation fronts, again indicating indiscriminate degradation. Thus, although oxidation is severe and most organic material is lost, lignin appears to go hand in hand with bulk $\mathrm{C}_{\mathrm{org}}$. This comparatively indiscriminate degradation is consistent with patterns observed (for carbohydrates and amino acids as well as lignin) at the F-turbidite oxidation front but contrasts with highly selective early degradation patterns observed in mixed-source, coastal marine environments (see Cowie et al., 1995, and references therein).

As also seen for the F-turbidite, nonpreferential loss of lignin across the oxidation front is in apparent contradiction to trends in $\delta^{13} \mathrm{C}_{\text {org }}$ values. These show values of $-20 \%$ o to $-21 \%$ in the unoxi- 


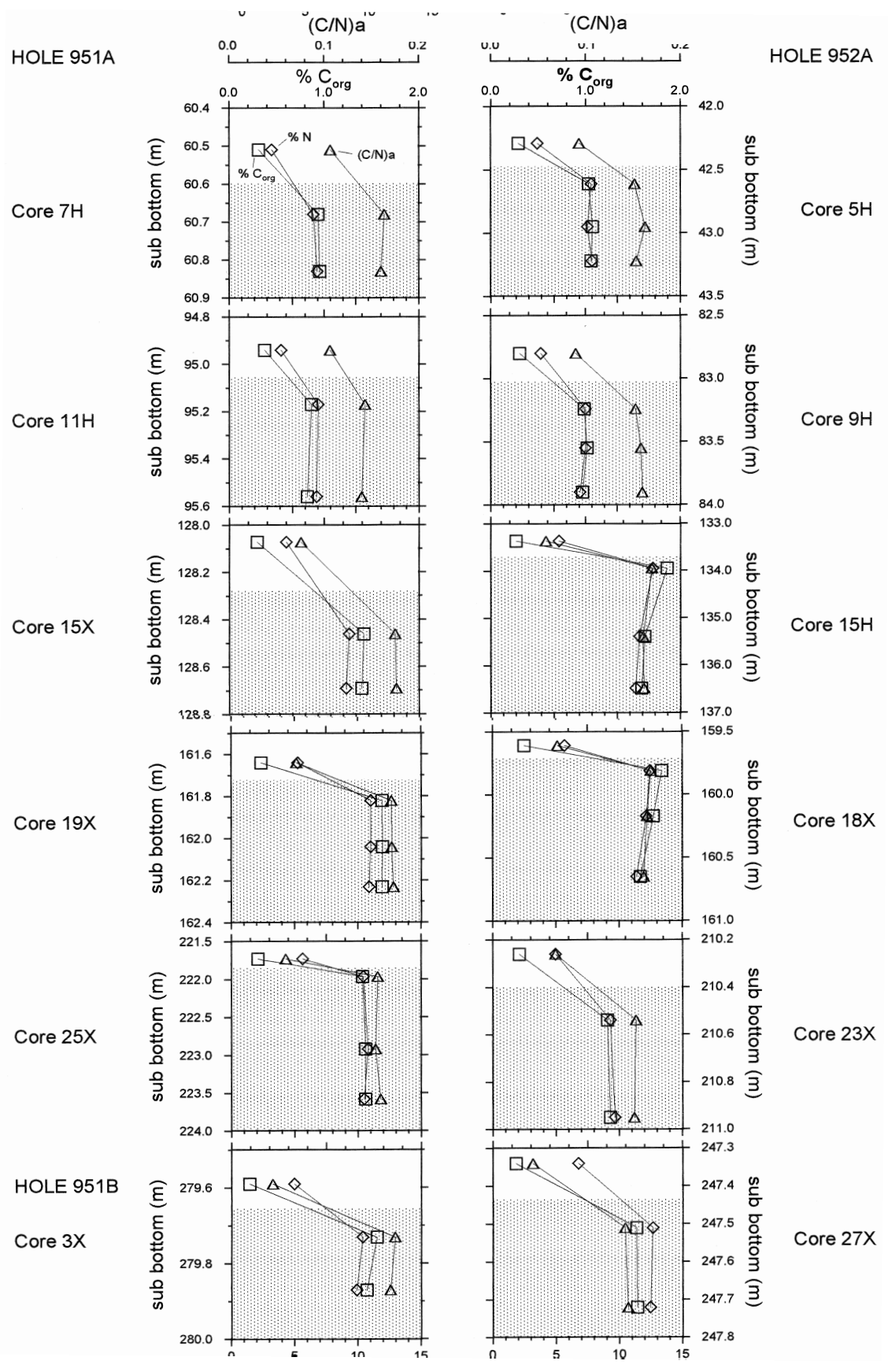

Figure 3. Plots of weight percent organic carbon $\left(\% \mathrm{C}_{\text {org }}\right.$ $=$ open squares $)$ and total $\mathrm{N}(\% \mathrm{~N}=$ open diamonds $)$ contents and atomic ratios of organic carbon to total nitrogen $[(\mathrm{C} / \mathrm{N}) \mathrm{a}=$ open triangles $]$ for samples spanning turbidite oxidation fronts in drill cores from Sites 951 and 952 . The fronts are indicated approximately by the transition from open to stippled areas. dized horizons (Fig. 5), consistent with predominantly marine organic material, but exhibit $1 \%$ o-2\%o shifts to lighter values in the oxidized horizons, as observed previously in MAP oxidation fronts (e.g., McArthur et al., 1992). Such trends, coupled with relative enrichments of terrestrial plant-wax $n$-alkanes observed across the " $\mathrm{f}$ " oxidation front (Prahl et al., 1997), would suggest preferential preservation of terrestrial relative to marine organic material. However, the lignin results, combined with a contradictory trend to lower $(\mathrm{C} /$ $\mathrm{N})$ a values, complete removal of pollen (Keil et al., 1994a), and nonpreferential loss of other biochemicals (amino acids and carbohydrates) at the F-turbidite oxidation front (Cowie et al., 1995), argue against such a process. A possible alternate explanation is that the $n$ alkanes are representative of other isotopically light materials that are preferentially preserved during the oxidation process and, along with the $\delta^{13} \mathrm{C}_{\text {org }}$ signatures, may become uncoupled from the bulk terrestri- al organic material that they are commonly used to trace. Further evidence for this comes from opposite trends in $\delta^{13} \mathrm{C}_{\mathrm{org}}$, to heavier values, across an active oxidation front in a Mediterranean sapropel, where lignin (and, by inference, terrestrial organic material) show slight preferential preservation (G. Cowie, unpubl. data). This issue remains to be resolved and is the subject of ongoing studies, but it is clear that considerable care must be taken before attributing trends in any single proxy to changes in the prevalence of organic matter type.

The stable $\mathrm{N}$-isotope signatures $\left(\delta^{15} \mathrm{~N}\right)$ of the unoxidized intervals are, like the other analytes, homogeneous, and, for all but one of the turbidites (Hole 951B, Section $3 \mathrm{X} ; \sim 8.3 \%$ ), fall in the quite narrow range of $\sim 4.5 \% 0-5.5 \%$ (Table 1 ) typical of many marine sediments (e.g., Altabet and Francois, 1994). However, there is a consistent shift to heavier values (Table 1; Fig. 5), occasionally by more than $2 \%$, in the oxidized horizons. These trends provide confirmation of previous 
Figure 4. Plot of organic carbon (wt\%) against total N (wt\%) contents. Linear regression lines and data are shown both for the whole sample set, and for the unoxidized turbidite intervals (open circles) only.
Figure 5. Plots of $\delta^{15} \mathrm{~N}\left(\%\right.$; open squares), $\delta^{13} \mathrm{C}_{\mathrm{org}}(\% \circ=$ open triangles), and $\mathrm{C}_{\text {org }}$-normalized total lignin phenol yields $\left(\Lambda=\mathrm{mg} / 100 \mathrm{mg} \mathrm{C}_{\text {org }}\right)$ for two turbidite oxidation fronts each from Sites 951 and 952 . The fronts are indicated approximately by the transition from open to stippled areas.
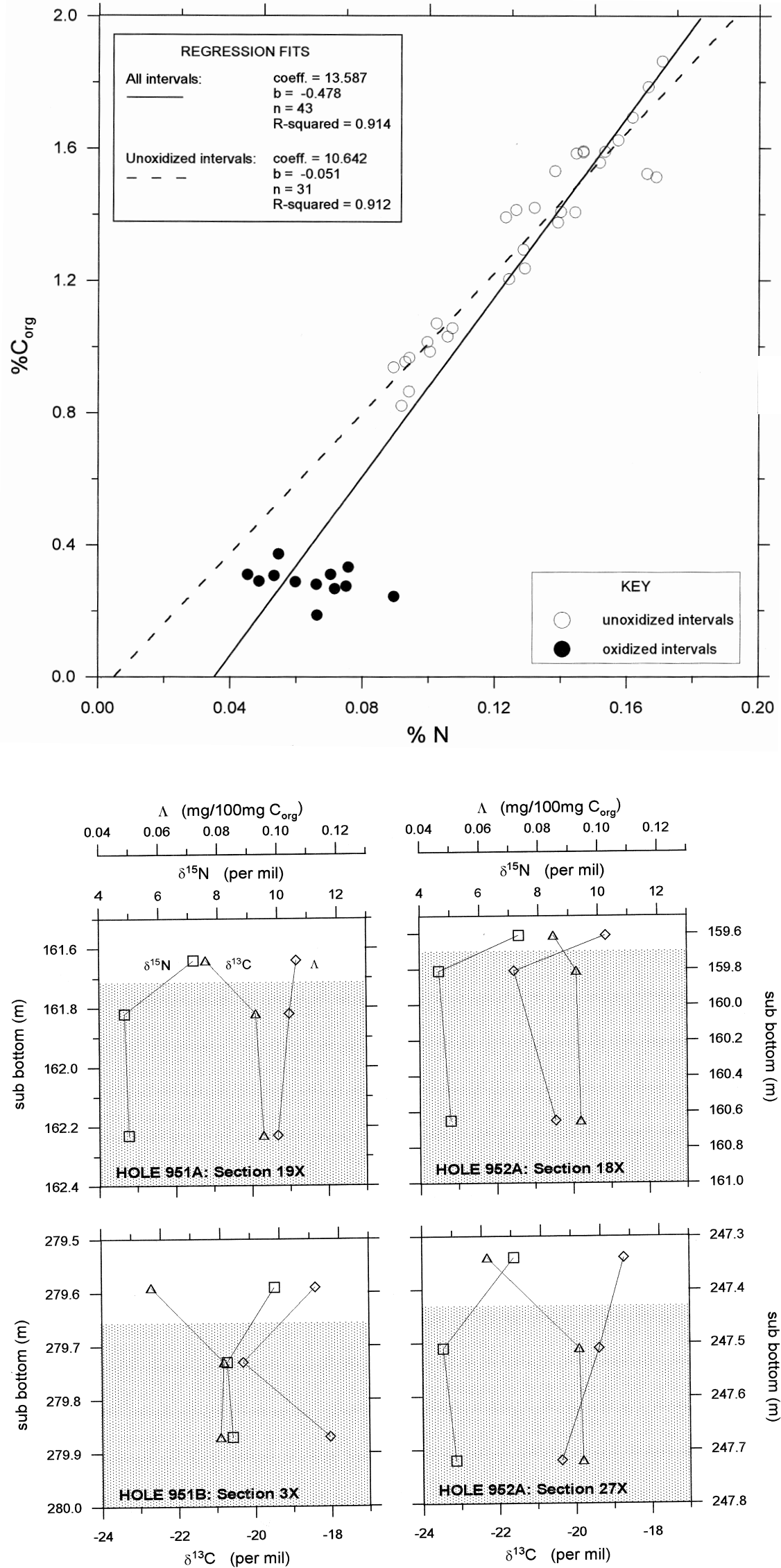
studies that have indicated preferential remineralization of ${ }^{14} \mathrm{~N}$ under oxidizing conditions in pelagic marine environments (e.g., Altabet and Francois, 1994). Taken at face value, the trends to heavier values also argue against significant preferential preservation of (isotopically light) terrestrial organic material, which can lead to shifts to lighter values in coastal sediments (G. Cowie, unpubl. data). However, given the possibility that the $\mathrm{N}$ content of the oxidized horizons is altered by adsorption or preferential preservation of inorganic $\mathrm{N}$ (see previous discussion) of unknown isotopic composition, the causes for the observed $\delta^{15} \mathrm{~N}$ trends cannot yet be confidently identified.

\section{Organic Carbon to Mineral Surface Area Relationships}

Recent studies by Mayer and Keil and their colleagues (e.g., Mayer, 1994a, 1994b; Keil et al., 1994c) have demonstrated that sorption of organic material onto mineral surfaces, and thus mineral surface area and hydrodynamic sorting, are important controls on the amount and quality of organic matter that accumulates in marine sediments. Sorption appears to protect otherwise labile organic material by rendering it inaccessible to bacteria or their enzymes (Keil et al., 1994b). Typically, the great majority of organic material is strongly adsorbed, and a remarkably constant relationship (roughly equivalent to "monolayer" coverage, as observed, for example, in natural, monomolecular organic films at the air/sea interface [Mayer, 1994a, and references therein]) is found between organic matter content and mineral surface area in a wide range of soils and continental margin sediments (Keil et al., 1994b; Mayer, 1994a). Thus, for example, large variability in the organic matter content of shelf and slope sediments on the Washington-Oregon margin, all exhibiting "monolayer coverage" ( 0.5$1.0 \mathrm{mg} \mathrm{C} \mathrm{Corg}_{2} / \mathrm{m}^{2}$ ) can be explained by differences in mineral surface area, which result from hydrodynamic sorting of the particulate load carried by the Columbia River (Keil et al., 1994c).

It is clear, however, that a "monolayer" sorptive organic matter loading is not an inviolable threshold. Extensive exposure to oxygen, as occurs in heavily reworked deltaic sediments or in slowly accumulating pelagic sediments where the overlying water column is long and oxygen penetration is deep, leads to $\mathrm{C}_{\text {org }}$ loadings well below the "monolayer equivalent" (Hedges and Keil, 1995). Such observations led these authors to propose that sedimentary organic matter content is determined largely by a delicate balance between sorptive preservation and exposure to oxygen, with a transition zone between these controls occurring somewhere on the lower continental slope.

The measured surface areas (SA) of the unoxidized intervals of the 12 turbidites studied here vary substantially (from $\sim 18$ to $44 \mathrm{~m}^{2} /$ g) without a clear downhole pattern, but show uniformity within a given turbidite, as observed for other analytes (Table 1). In general, SA values are high where $\mathrm{CaCO}_{3}$ contents are low (Table 1; Fig. 6). With only one exception (Core 157-951A-7H), SAs increase across the oxidation fronts. These trends again mirror those of $\mathrm{CaCO}_{3}$, with the largest increases in SA being associated with the most distinct decreases in $\mathrm{CaCO}_{3}$ (Fig. 6). Thus, sediment SA also is affected by the oxidation process that leads to removal of the majority of the turbidite organic material. The differing $\mathrm{CaCO}_{3}$ of the turbidites may be caused by different inputs to the source region or by environmental conditions (e.g., CCD) at the time of deposition. The inverse $\mathrm{SA}: \mathrm{CaCO}_{3}$ relationship may be explained by the fact that sedimentary $\mathrm{CaCO}_{3}$ primarily occupies the coarser sediment fractions (lower $\mathrm{SA}$ ) and is removed by dissolution associated with organic matter oxidation.

To place the oxidative organic matter losses observed at the MAP oxidation fronts in the context of the Hedges and Keil (1995) sorptive preservation vs. oxygen exposure model, it is necessary to relate measured $\mathrm{C}_{\text {org }}$ contents to those expected for "monolayer coverage" of available mineral SA (Fig. 7). This shows that loadings in the unoxidized turbidites are at or slightly below the lower limit of the $0.5-1.0$ $\mathrm{mg} \mathrm{C}_{\text {org }} / \mathrm{m}^{2}$ "monolayer equivalent" that is consistent with their proposed origin on the continental margins of northwest Africa. Al- though the exact origins of debris flows associated with turbidite events remain unclear, a possible explanation for the "submonolayer" $\mathrm{C}_{\text {org }}$ loadings in some of the unoxidized turbidites is that they were already buried and partially degraded at their place of origin. This is consistent with the measured amino acid and carbohydrate compositions of the unoxidized F-turbidite (Cowie et al., 1995), which showed clear signs of substantial alteration relative to surficial continental margin sediments. It is also consistent with the findings of Weaver (1994), who, for the recent F-turbidite, for example, calculated an erosion depth of $52 \mathrm{~m}$ on the northwest African margin and, based on ${ }^{14} \mathrm{C}$ dating and microfossil compositions, considerable input of material as old as $500 \mathrm{k} . \mathrm{y}$.

The severe oxidation at the oxidation fronts consistently leads to reduced $\mathrm{C}_{\text {org }}$ :SA ratios (Fig. 7) and, in all but one case (Core 157951A-7H), markedly lower "submonolayer" coverage in the oxidized intervals. Although partly caused by SA increase as well as $\mathrm{C}_{\text {org }}$ loss, this phenomenon is entirely consistent with the Hedges and Keil (1995) model. The unoxidized turbidite samples originally have a "near-monolayer" or "monolayer" sorptive organic matter coverage, as is typical of sediments on continental margins that are rapidly removed from contact with oxygen (short water column, rapid sedimentation rates, and shallow oxygen penetration). When these sediments are transferred to the abyssal plain and are exposed to oxygen at oxidation fronts, $\mathrm{C}_{\text {org }}$ loadings drop substantially to "submonolayer" values typical of organic matter-poor sediments commonly found in the pelagic setting where oxygen exposure is extensive (long water column, slow sedimentation rates, and deep oxygen penetration). The nature of, and cause for, the relatively uniform background $\mathrm{C}_{\text {org }}$ concentration, which survives oxidation in the oxidized turbidites and normal pelagic sediments, remains unclear. Whether it is the result of an additional physical preservation mechanism or of the selective preservation of a recalcitrant (and ubiquitous) organic component is the subject of ongoing studies.

\section{SUMMARY}

The results of this study clearly show that the turbidite sequences (and associated oxidation fronts) previously observed in the upper 30 $\mathrm{m}$ of MAP sedimentary records extend for hundreds of meters. Extensive organic matter loss at the oxidation fronts and associated decreases in $\mathrm{C}: \mathrm{N}$ ratios (possibly from adsorption of ammonia) are also recurring phenomena. Although the initial organic matter contents of the organic matter-rich turbidites are variable-apparently because of differing inputs or preservation of organic material, with an average $(\mathrm{C} / \mathrm{N})$ a of $\sim 12$ - the final $\mathrm{C}_{\text {org }}$ contents of the oxidized intervals are relatively uniform and closely resemble those of typical organic matter-poor pelagic sediments. Despite the severity of the oxidation, it would appear that lignin losses parallel those of bulk $\mathrm{C}_{\text {org }}$ and, thus, throw into question whether shifts to lighter $\delta^{13} \mathrm{C}_{\text {org }}$ values are indicative of preferential loss of marine relative to terrestrial organic material or to uncoupled diagenetic behavior. In contrast, there are clear shifts to heavier $\delta^{15} \mathrm{~N}$ values across the oxidation fronts. These are consistent with previously observed early diagenetic trends in oxygenated pelagic settings. The degree to which they reflect isotopic fractionation during organic matter alteration remains uncertain, however, because of apparent selective preservation or immobilization of inorganic $\mathrm{N}$ (of unknown isotopic signature).

The mineral surface areas of the unoxidized turbidites are quite variable and generally inversely related to $\mathrm{CaCO}_{3}$ content, indicating that differing carbonate contents or preservation, as well as clay content, are important controls on SA in these deposits. The inverse $\mathrm{SA}: \mathrm{CaCO}_{3}$ relationship extends across the oxidation fronts, with a rise in SA apparently caused by dissolution of $\mathrm{CaCO}_{3}$. Across the oxidation fronts, organic $\mathrm{C}$ contents drop from near "monolayer equivalent" sorptive loadings typical of suboxic, continental margin sediments to markedly lower, "submonolayer" loadings typical of sedi- 


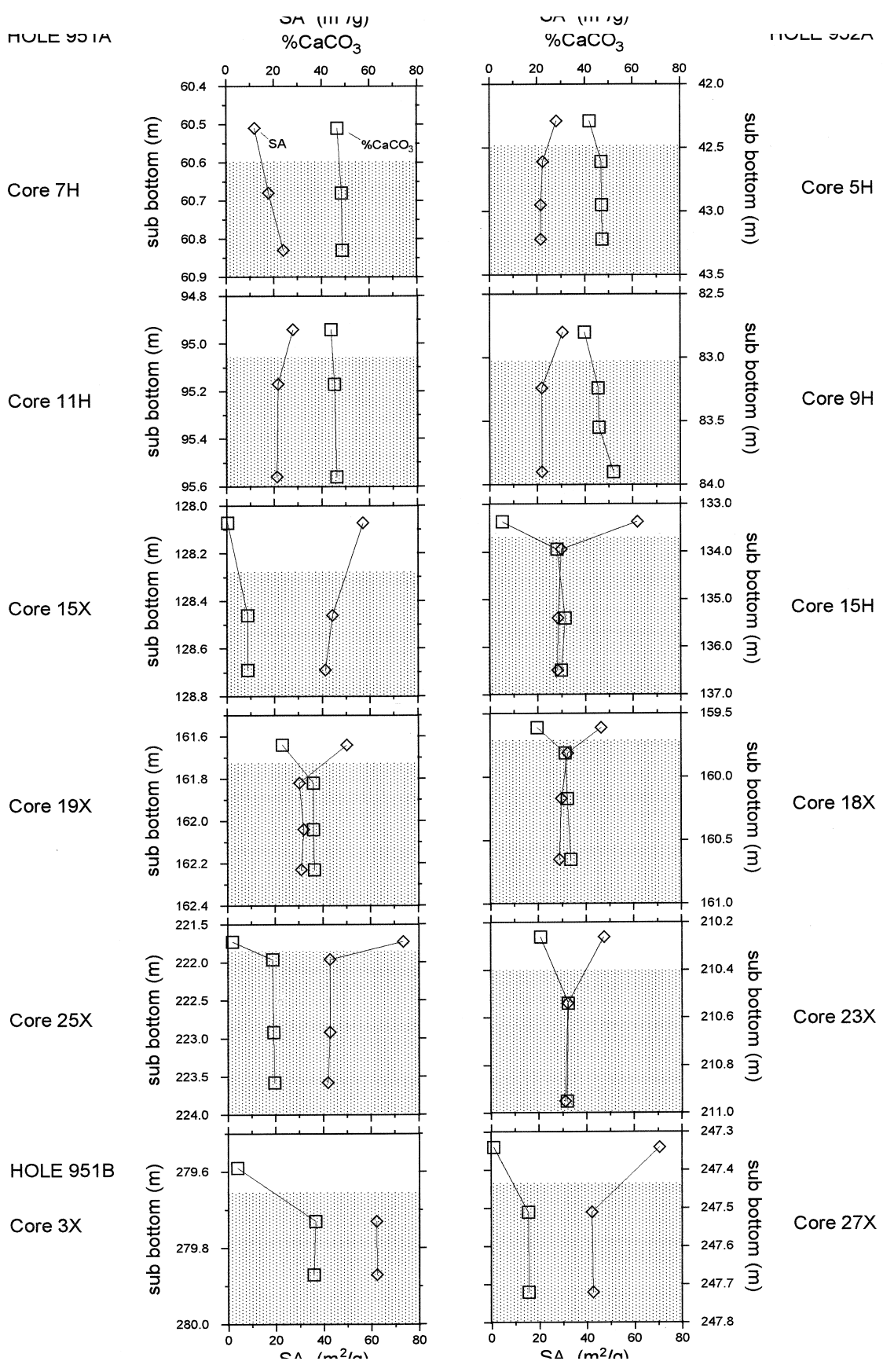

Figure 6. Plots of $\mathrm{CaCO}_{3}$ (wt \%) content (open squares) and mineral surface area (SA; open diamonds) for samples spanning turbidite oxidation fronts in drill cores from Sites 951 and 952 . The fronts are indicated approximately by the transition from open to stippled areas.

ments from oxygenated pelagic settings. When compared with the strikingly lower loadings in the oxidized horizons, the overall similarity of $\mathrm{C}_{\mathrm{org}}$ : $\mathrm{SA}$ loadings within the different unoxidized turbidites, and the uniformity within given turbidites over million-year time scales (Fig. 7) highlight the effects of short-term oxygen exposure relative to long-term anaerobic diagenesis. These results demonstrate the potential usefulness of $\mathrm{C}_{\mathrm{org}}: \mathrm{SA}$ as a comparative parameter indicative of organic matter origin and diagenetic history.

The central implication of these collected observations is a confirmation that, in the pelagic setting, exposure to oxygen is a primary control on sedimentary organic matter content. The effect of the oxidation process at the MAP turbidite oxidation fronts is striking; deposits with an organic content and composition typical of continental margin sediments are preserved for extended periods in the absence of oxygen, but they are effectively converted to typical, organic matter-poor pelagic sediments when exposed to oxygen on the MAP.

\section{ACKNOWLEDGMENTS}

We are indebted to B. Nielsen, E. Tsamakis, and M. Soon and colleagues for $\mathrm{N}$-isotope, surface area, and elemental analyses, respectively. We are also grateful to J. Rullkötter and R. Tyson for thorough and insightful reviews. This research was supported by the Natural Science and Engineering Council of Canada.

\section{REFERENCES}

Altabet, M.A., and Francois, R., 1994. Sedimentary nitrogen isotopic ratio as a record for surface ocean nitrate utilization. Global Biogeochem. Cycles, 8:103-116.

Calvert, S.E., and Pedersen, T.F., 1992. Organic carbon accumulation and preservation in marine sediments: how important is anoxia? In Whelan, J.K., and Farrington, J.W. (Eds.), Organic Matter: Productivity, Ассити- 
lation and Preservation in Recent and Ancient Sediments: New York (Columbia Univ. Press), 231-263.

Canfield, D.E., 1994. Factors influencing organic carbon preservation in marine sediments. Chem. Geol., 114:315-329.

Cowie, G.L., Hedges, J.I., Prahl, F.G., and de Lange, G.J., 1995. Elemental and major biochemical changes across an oxidation front in a relict turbidite: an oxygen effect. Geochim. Cosmochim. Acta, 59:33-46.

De Lange, G.J., 1992. Distribution of exchangeable, fixed, organic and total nitrogen in interbedded turbiditic/pelagic sediments of the Madeira abyssal plain, eastern North Atlantic. Mar. Geol., 109:95-114.

De Lange, G.J., Jarvis, I., and Kuijpers, A., 1987. Geochemical characteristics and provenance of late Quaternary sediments from the Madeira Abyssal Plain, North Atlantic. In Weaver, P.P.E., and Thomson, J. (Eds.), Geology and Geochemistry of Abyssal Plains. Geol. Soc. Spec. Publ. London, 31:147-165.

de Leeuw, J.W., Viets, T.C., Schenk, P.A., and Boon, J.J., 1982. A comparative study of eight sediment samples from the Canary basin and nine sediment samples from the Angola basin by Curie-point pyrolysis mass spectrometry. Rep. TH Delft-FOM Amsterdam, 1-6.

Demaison, G.J., and Moore, G.T., 1980. Anoxic environments and oil source bed genesis. AAPG Bull., 64:1179-1209.

Hedges, J.I., Clark, W.A., and Cowie, G.L., 1988. Organic matter sources to the water column and surficial sediments of a marine bay. Limnol. Oceanogr., 33:1116-1136.

Hedges, J.I., and Ertel, J.R., 1982. Characterization of lignin by capillary gas chromatography of cupric oxide oxidation products. Anal. Chem., 54:174-178.

Hedges, J.I., and Keil, R.G., 1995. Sedimentary organic matter preservation: an assessment and speculative synthesis. Mar. Chem., 49:81-115.

Hedges, J.I., and Mann, D.C., 1979. The characterization of plant tissues by their lignin oxidation products. Geochim. Cosmochim. Acta, 43:18031807.

Keil, R.G., Hu, F.S., Tsamakis, E.C., and Hedges, J.I., 1994a. Pollen in marine sediments as an indicator of oxidation of organic matter. Nature, 369:639-641.

Keil, R.G., Montluçon, D.B., Prahl, F.G., and Hedges, J.I., 1994b. Sorptive preservation of labile organic matter in marine sediments. Nature, 370:549-551.
Keil, R.G., Tsamakis, E., Fuh, C.B., Giddings, C., and Hedges, J.I., 1994c. Mineralogical and textural controls on organic composition of coastal marine sediments: hydrodynamic separation using SPLITT-fractionation. Geochim. Cosmochim. Acta, 57:879-893.

Mayer, L.M., 1994a. Relationships between mineral surfaces and organic carbon concentrations in soils and sediments. Chem. Geol., 114:347-363.

, 1994b. Surface area control of organic carbon accumulation in continental shelf sediments-a hypothesis. Geochim. Cosmochim. Acta, 58:1271-1284.

McArthur, J.M., Tyson, R.V., Thomson, J., and Mattey, D., 1992. Early diagenesis of marine organic matter: alteration of the carbon isotopic composition. Mar. Geol., 105:51-61.

Müller, P.J., 1977. C/N ratios in Pacific deep sea sediments: effect of inorganic ammonium and organic nitrogen compounds sorbed by clays. Geochim. Cosmochim. Acta, 41:765-776.

Prahl, F.G., de Lange, G.J., Lyle, M., and Sparrow, M.A., 1989. Post-depositional stability of long-chain alkenones under contrasting redox conditions. Nature, 341:434-437.

Prahl, F.G., De Lange, G.J., Scholten, S., and Cowie, G.L., 1997. A case for postdepositional aerobic degradation of terrestrial organic matter in turbidite deposits from the Madeira Abyssal Plain. Org. Geochem., 27:141152.

Shipboard Scientific Party, 1995. Background, objectives, and principal results of Madeira Abyssal Plain drilling. In Schmincke, H.-U., Weaver, P.P.E., Firth, J.V., et al., Proc. ODP, Init. Repts., 157: College Station, TX (Ocean Drilling Program), 5-10.

Tyson, R.V., 1995. Sedimentary Organic Matter: Organic Facies and Palynofacies: London (Chapman and Hall).

Weaver, P.P.E., 1994. Determination of turbidity current erosional characteristics from reworked coccolith assemblages, Canary Basin, north-east Atlantic. Sedimentology, 41: 1025-1038.

Date of initial receipt: 8 July 1996

Date of acceptance: 21 January 1997

Ms 157SR-150

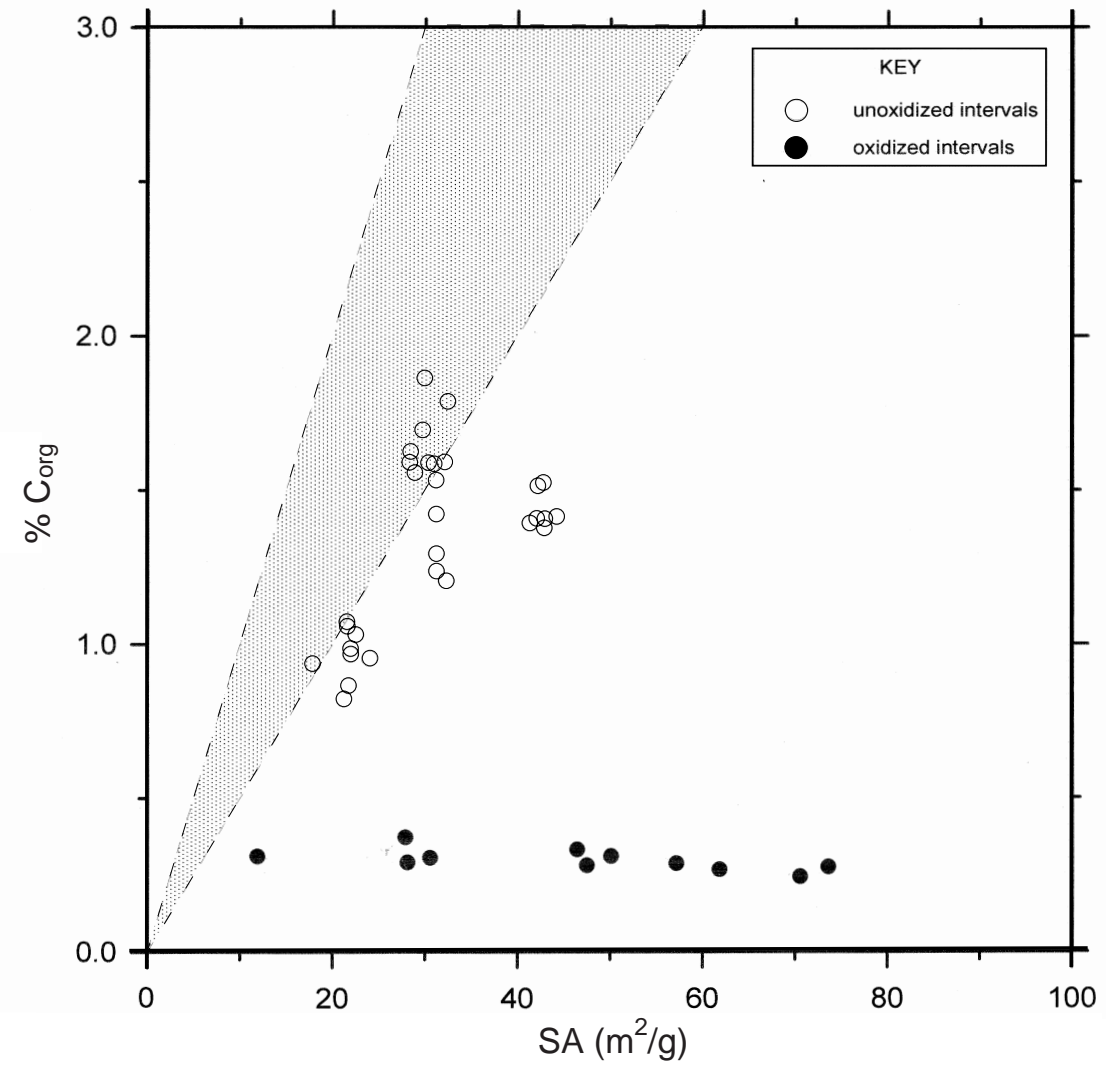

Figure 7. A plot of measured organic carbon (wt $\%$ ) against mineral surface area $\left(\mathrm{m}^{2} / \mathrm{g}\right)$ for unoxidized (open circles) and oxidized (solid circles) turbidite horizons. The shaded area represents the range of loadings equivalent to "monolayer" coverage of available surface area $\left(\sim 0.5-1.0 \mathrm{mg} \mathrm{C}\right.$ org $/ \mathrm{m}^{2}$; Mayer, 1994a; Hedges and Keil, 1995). 